Annual Reports on the Progress of Chemistry for 1942

Vol. 39. Pp. xxviii+257. (London: Chemical Society, 1943.) $15 s$.

CINCE it is no longer profitable to attempt to $S$ review progress along the whole chemical 'front' in a volume which is meant to be read, these annual reports have been deliberately restricted in scope, whereby surely their appeal has been widened. Each year a number of important topics are selected for detailed discussion, so that representative pictures of progress in various fields of investigation are presented as a kind of 'album'. Paper shortage has on this occasion prevented inclusion of sections on analytical chemistry and on radioactivity and sub-atomic phenomena; but general and physical chemistry, inorganic chemistry, crystallography, organic chemistry and biochemistry are well represented.

G. Gee discusses the physical chemistry of rubber solutions; C. E. H. Bawn deals with the atomic reactions of the alkali metals; and W. F. Berg examines the physical chemistry of latent-image formation in gelatin - silver halide emulsions. H. J. Emeléus's brief review of progress in inorganic chemistry is based on general interest rather than on specialist value. A. L. G. Rees follows with an account of the luminescence of inorganic solids, and A. J. E. Welch illustrates some applications of modern technique in inorganic chemistry. J. M. Robertson's report on erystallography relates to the technique of structure analysis as well as to recent data for certain inorganic and organic structures. Organic chemistry is represented by the following subjects : stereochemistry (M. P. Balfe and J. Kenyon), general methods (F. S. Spring), the lignin problem (E. G. V. Percival), polycyclic aromatic compounds (J. W. Cook) and heterocyclic compounds (T. S. Stevens). Biochemistry is not on this occasion. represented by the vitamins; instead, L. J. Harris discusses nutrition with special reference to trace elements, C. G. Anderson reviews the more outstanding developments since 1940 in immunochemistry, J. L. Cranmer and A. Neuberger briefly summarize recent advances relating to the proteolytic enzymes, and F. W. Norris gives an account of recent work on some plant products and enzymes.

\section{Topographical Anatomy of the Dog}

By Dr. O. Charnock Bradley. Revised by Prof. Tom Grahame. Fourth edition. Pp. xii $+316+9$ plates. (Edinburgh and London: Oliver and Boyd, Ltd., 1943.) 28s. net.

THE contents of this standard book are so well known and clearly indicated in the title that it is not necessary to review them. This edition has been revised by Prof. Tom Grahame and, while the bulk of it remains the same, there has been a certain amount of revision and three noteworthy alterations. First, after the descriptions of most of the muscles, a brief note on the function of each has been appended. Secondly, the number of illustrations has increased from 91 to 128 plus a frontispiece. The frontispiece is that of the skeleton of the dog, the majority of the new text-figures are of bones to illustrate the position of the origins and insertions of the muscles, and the last, accompanied by about three pages of description, is to illustrate the superficial lymph vessels and nodes. Thirdly, the new edition contains nine radiographs well reproduced upon plates. These three additions add materially to the usefulness of the book from the student's point of view. There is perhaps one criticism that can be made of the radio. graphs and that is, seeing it is the student's first introduction to these valuable aids, they might be more fully labelled and explained in the accompanying legends.

The whole book reflects considerable credit on editor and producer alike, and, while primarily intended for the veterinarian, it will be found most useful to anyone interested in comparative anatomy.

\section{An Easy Outline of Astronomy}

By Dr. M. Davidson. (Thinker's Library, No. 95.) Pp. iv + 108+2 plates. (London: Watts and Co., Ltd., 1943.) 2s. $6 d$. net.

$\mathrm{W}$ ITH astonishing versatility the Rev. Dr. M. Davidson turns from philosophy to give us this little volume on general astronomy. The reader who has no previous acquaintance with the subject can master the book without mental indigestion, and will leave it with a working knowledge of the elements of descriptive astronomy. The author gives an upto-date account of our knowledge of the movements, dimensions, masses and compositions of the heavenly bodies without dealing with the identification of the constellations and individual stars. A fow errors have been noted: among those which the student will find most puzzling are contradictory statements (pp. 55, 56) on the proportion of comets with retrograde motion, and a loose construction (p. 31) which makes it appear that solar eclipses which are not total are annular. In a section (p. 68) dealing with the transformation of mass into radiation, Dr. Davidson is betrayed into assuring his readers that "when we burn a piece of coal, the weight of its ashes and the smoke emitted is very nearly the same as the original weight of the coal"- -surely a statement that would make Lavoisier turn in his grave! But these are minor points which do not detract seriously from the merits of this authoritative presentation of the salient facts of astronomy in a form suited to the complete novice.

A. $\mathrm{H}$.

\section{Beyond the Microscope}

Being an Account of a Voyage of Discovery in the Borderland Country between the 'Living' Organism. and the 'Non-living' Chemical. By Kenneth M. Smith. (Pelican Books, A.119.) Pp. $12+4$ plates. (Harmondsworth and New York: Penguin Books, Ltd., 1943.) 9d. net.

THHIS volume covers the whole sphere of virus diseases in plants and animals and their in. vestigation. The structure of viruses is discussed and illustrated by photographs taken by means of the electron microscope. Among the chapter head. ings are "Viruses and Tumours" and "Combating the. Viruses". The scope is remarkably wide, but the presentation is clear and the book makes most interesting reading.

\section{Human Physiology}

By Kenneth Walker. (Pelican Books, A.102.) Pp. $128+2$ plates. (Harmondsworth and New York: Penguin Books, Ltd., 1943.) $9 d$. net.

THIS is an elementary account of human physio. logy for the layman written in simple language and essentially concerned with the bearing of physiology on health. Line drawings in the text follow the time-honoured tradition that no book on physiology should be well illustrated. 